W. I. Winters

Central Files

O.S.T.I. (2)

R2-12

L8-04

L8-07

$X$
$X$
$X$

OFFSITE

U. S. Department of Energy - Headquarters

Office of Environmental Restoration and

Waste Management EM-563

12800 Middlebrook Road

Germantown, MD 20874

K. T. Lang

J. A. Poppiti

$X$
$X$

Los Alamos Technical Associates

750 Swift, Suite 14

Richland, WA 99352

A. T. Dicenso

C. J. Lindquist

T. T. Tran

G. P. Westleigh

$x$

$x$

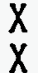




\section{DISCLAIMER}

Portions of this document may be illegible in electronic image products. Images are produced from the best available original document. 


\section{DISTRIBUTION SHEET}

\begin{tabular}{|c|c|c|c|c|c|}
\hline \multirow{2}{*}{$\begin{array}{l}\text { To } \\
\text { Distribution }\end{array}$} & \multirow{2}{*}{\multicolumn{3}{|c|}{$\begin{array}{l}\text { From } \\
\text { Characterization Support }\end{array}$}} & \multicolumn{2}{|c|}{ Page 1 of 2} \\
\hline & & & & \multicolumn{2}{|c|}{ Date $4 / 24 / 95$} \\
\hline \multirow{2}{*}{\multicolumn{4}{|c|}{ Project Title/Work Order }} & \multicolumn{2}{|c|}{ EDT No. 611602} \\
\hline & & & & \multicolumn{2}{|l|}{ ECN No. } \\
\hline Name & MSIN & $\begin{array}{c}\text { Text } \\
\text { With } \\
\text { All } \\
\text { Attach. }\end{array}$ & Text Only & $\begin{array}{l}\text { Attach./ } \\
\text { Appendix } \\
\text { Oniy }\end{array}$ & $\begin{array}{c}\text { EDT/ECN } \\
\text { Only }\end{array}$ \\
\hline
\end{tabular}

QNSITE

U. S. Department of Enerqy -

Rirhland Field Office

P. R. Hernandez

W. I.iou

N. W. Willis

MAr.TEC

J. D. Haney

Parific Northwest Laboratories

S. S. Mckinley

J. T. Slankas

We tinghouse Hanford Company

R. Akita

R. N. Campeau

T. F. Dale

S. J. Eberlein

C. A. Esvelt

G. D. Forehand

R. K. Fuller

V. H. Hall

W. J. Kennedy

J. G. Kristofzski

M. J. Kupfer

J. S. Lee

A. D. Olguin

A. D. Rice

L. M. Sasaki

P. Sathyanarayana (2)

J. S. Schofield

R. D. Schreiber (2)

R. H. Stubbs

C. L. Thomas

T. C. Trible

M. 1). Webb

$\begin{array}{ll}\text { S7-54 } & X \\ \text { S7-54 } & X \\ \text { S7-54 } & X\end{array}$

57-73 $X$

P7-22 $\quad X$

K9-81 X

T6-20 $X$

S7-04 $X$.

T6-20

R2-12

S7-12

S7-31

T6-31

H4-19

S7-03

T6-06

H5-49

S7-03

S7-04

T6-06

R2-12

R2-12

S7-12

R2-12

S7-12

H4-19

S1-57

H4-25

$X$
$X$
$X$

$x$

$x$

$x$
$x$
$x$
$x$
$x$
$x$
$x$
$x$
$x$
$x$
$x$
$x$
$x$
$x$
$x$
$x$
$x$
$x$




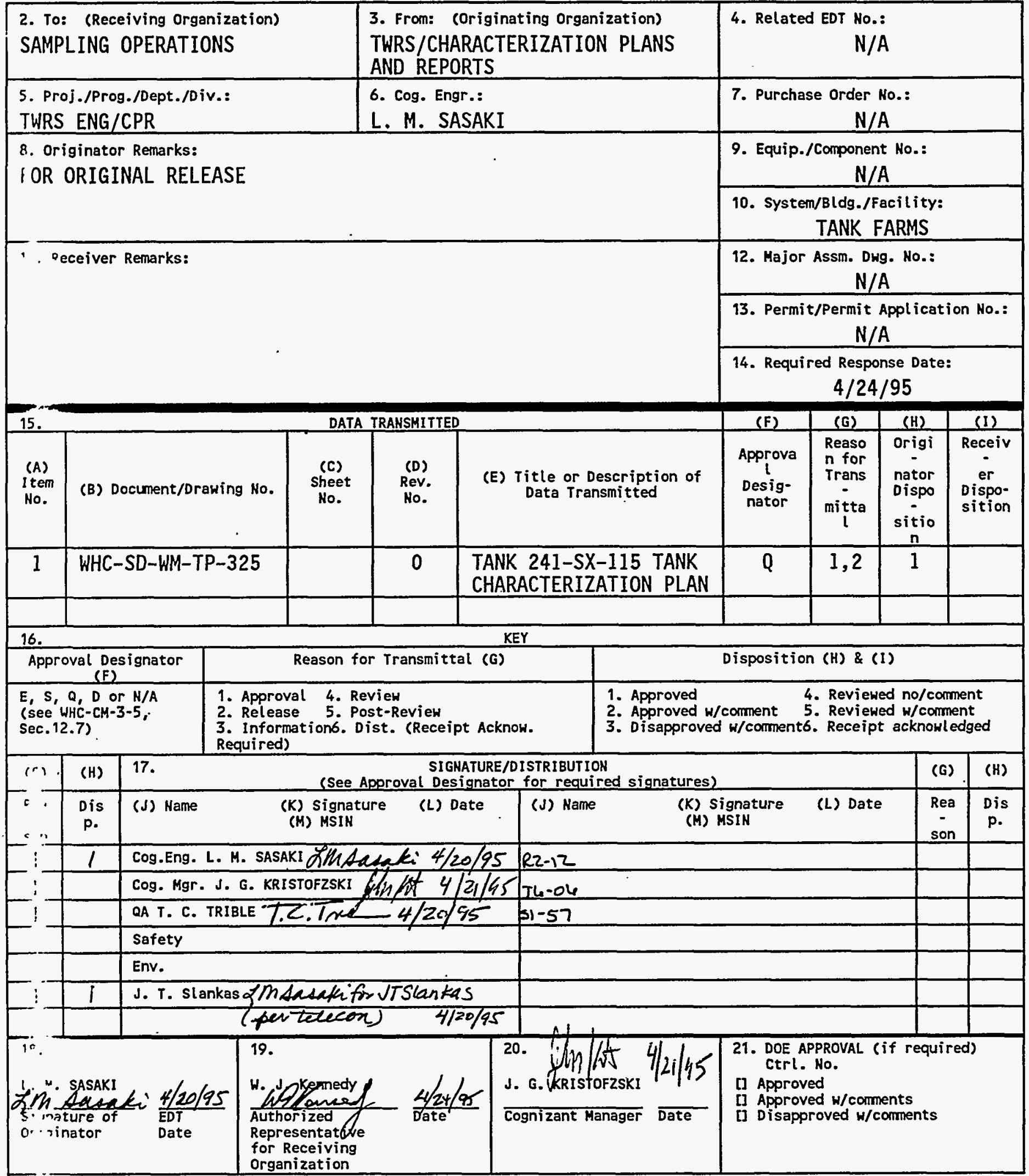




\section{RELEASE AUTHORIZATION}

Document Number: WHC-SD-WM-TP-325, REV 0

Document Title: Tank 241-SX-115 Tank Characterization Plan

Release Date: $\quad 4 / 24 / 95$

\section{This document was reviewed following the procedures described in WHC-CM-3-4 and is:}

\section{APPROVED FOR PUBLIC RELEASE}

\section{WHC Information Release Administration Specialist:}

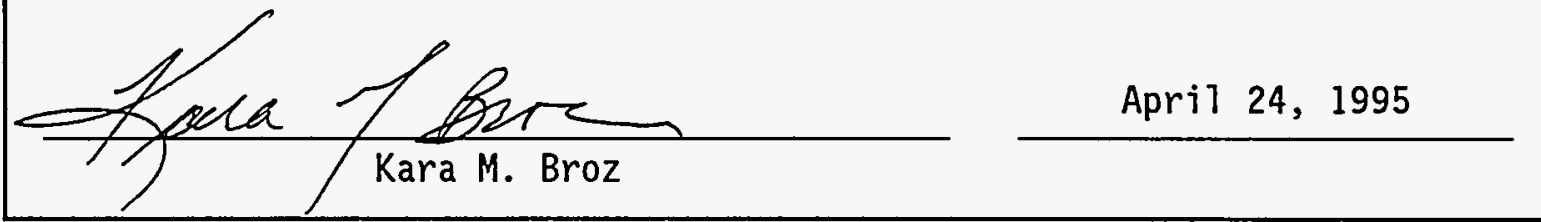

TRADEMARK DISCLAIMER. Reference herein to any specific commercial product, process, or service by trade name, trademark, manufacturer, or otherwise, does not necessarily constitute or imply its endorsement, recommendation, or favoring by the United States Goverment or any agency thereof or its contractors or subcontractors.

This report has been reproduced from the best available copy. Available in paper copy and microfiche. Printed in the United States of America. Available to the U.S. Department of Energy and its contractors from:

U.S. Department of Energy

Office of Scientific and Technical Information (OSTI)

P.0. $80 \times 62$

Oak Ridge, IN 37831

Telephone: (615) $576-8401$

Available to the public from:

U.S. Department of Cormerce

National Technical Information Service (NT.1S)

5285 Port Royal Road

Springfield, VA 22161

Telephone: (703) 487-4650 
2. Title

TANK 241-SX-115 TANK CHARACTERIZATION PLAN

5. Key Words

CHARACTERIZATION, SAFETY SCREENING, SINGLE-SHELL

TANK, SAMPLING, ANALYSIS, TANK CHARACTERIZATION

PLAN, NON-WATCH LIST
3. Number

WHC-SD-WM-TP-325

6. Author

Name: L. M. SASAKI S.M. Aacak: 4/20/95

Organization/Charge Code

\section{Abstract}

This document is a plan which serves as the contractual agreement between the Characterization Project, Sampling Operations, and WHC 222-S Laboratory. The scope of this plan is to provide guidance for the sampling and analysis of samples for tank 241-SX-115.

8.

RELEASE STAMP

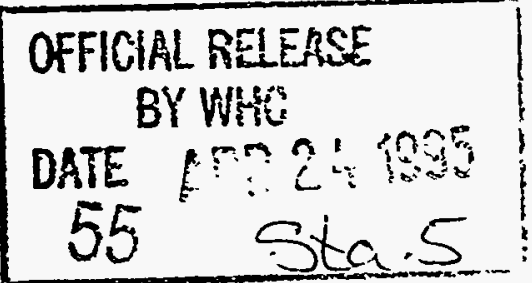


WHC-SD-WM-TP-325

Revision 0

\title{
Tank 241-SX-115 \\ Tank Characterization Plan
}

\section{DISCLAIMER}

This report was prepared as an account of work sponsored by an agency of the United States Government. Neither the United States Government nor any agency thereof, nor any of their employees, makes any warranty, express or implied, or assumes any legal liability or responsibility for the accuracy, completeness, or usefulness of any information, apparatus, product, or process disclosed, or represents that its use would not infringe privately owned rights. Reference herein to any specific commercial product, process, or service by trade name, trademark, manufacturer, or otherwise does not necessarily constitute or imply its endorsement, recommendation, or favoring by the United States Government or any agency thereof. The views and opinions of authors expressed herein do not necessarily state or reflect those of the United States Government or any agency thereof.

\section{Prepared for the U.S. Department of Energy \\ Office of Environmental Restoration and Waste Management}

by

\author{
Los Alamos Technical Associates \\ 8633 Gage Boulevard \\ Kennewick, Washington 99336
}


WHC-SD-WH-TP-325, Rev. 0

TABLE OF CONTENTS

1.0 INTRODUCTION $\ldots \ldots \ldots \ldots \ldots \ldots \ldots \ldots$

2.0 DATA QUALITY OBJECTIVES APPLICABLE TO TANK 241-SX-115 . . . . . . . . 1

2.1 SAFETY SCREENING DATA QUALITY OBJECTIVES ................ 1

2.2 PRETREATMENT DATA QUALITY OBJECTIVES . . . . . . . . . . . . . 2

3.0 TANK AND WASTE INFORMATION ..................... 2

3.1 TANK STATUS .......................... 2

3.2 TANK CONFIGURATION . . . . . . . . . . . . . . . . . . . . . . . 2

3.3 TANK HISTORY .......................... 2

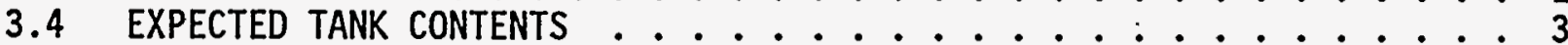

4.0 TANK SX-115 SCHEDULED SAMPLING EVENTS . . . . . . . . . . . . . 6

5.0 REFERENCES ........................ 7

APPENDICES

A: SAMPLING AND ANALYSIS P.LAN FOR AUGER SAMPLING IN FISCAL YEAR 1995 • . A- $\mathrm{A}$

LIST OF TABLES

3-1: Tank SX-115 Solid Composite Inventory Estimate . .............4 4

4-1: Integrated DQO Requirements ...................6 6

LIST OF FIGURES

3-1: Fil1 History of Tank 241-SX-115 . . . . . . . . . . . . . . 5

\section{LIST OF ABBREVIATIONS}

DNFSB Defense Nuclear Facilities Safety Board

DOE U.S. Department of Energy

DQO Data Quality Objective

DST Double-She7l Tank

RCRA Resource Conservation and Recovery Act of 1976

SAP Sampling and Anatysis Plan

SST Single-She11 Tank

SX-115 Tank 241-SX-115

TCP

TOC

TPA

TWRS

WHC

Tank Characterization Plan

Total Organic Carbon

Federal Facility Agreement and Consent Order (Tri-Party Agreement)

Tank Waste Remediation System

Westinghouse Hanford Company 


\subsection{INTRODUCTION}

The Defense Nuclear Facilities Safety Board (DNFSB) has advised the U.S. Department of Energy (DOE) to concentrate the near-term sampling and analysis activities on identification and resolution of safety issues (Conway 1993). The data quality objective (DQO) process was chosen as a tool to be used to identify the information needed for the resolution of safety issues. As a result, a revision in the Federal Facility Agreement and Consent Order (Tri-Party Agreement or TPA) milestone M-44 has been made, which states that "A Tank Characterization Plan (TCP) will be developed for each double-shell tank (DST) and single-shell tank (SST) using the DQO process .... Development of TCPs by the DQO process is intended to allow users (e.g., Hanford Facility user groups, regulators) to ensure their needs will be met and that resources are devoted to gaining only necessary information" (Ecology et al, 1994). This document satisfies that requirement for tank 241-SX-115 (SX-115) sampling activities.

\subsection{DATA QUALITY OBJECTIVES APPLICABLE TO TANK 241-SX-115}

The sampling and analytical needs associated with the Hanford Site underground storage tanks on one or more of the four Watch Lists (ferrocyanide, organic, flammable gas, and high heat) and the safety screening of all 177 tanks have been identified through the DQO process. A.DQO identifies the information needed by a program group concerned with safety issues, regulatory requirements, tank waste processing, or the transport of tank waste. The DQOs that have beenm completed and are applicable to tank $S X-115$ are discussed in the following sections.

\subsection{SAFETY SCREENING DATA QUALITY OBJECTIVES}

The Tank Safety Screening Data Quality Objective (Babad and Redus 1994) describes the sampling and analytical requirements that are used to screen the waste tanks for unidentified safety issues. Both Watch List and non-Watch List tanks will be sampled and evaluated to classify waste tanks into one of three categories (SAFE, CONDITIONALLY SAFE, or UNSAFE). The safety screening DQO identifies the guidel ines to determine to which classification a tank belongs based on analyses that indicate if certain measurements are within certain parameters. The primary analytical requirements for the safety screening of a tank are energetics, total alpha activity, moisture content, and flammable gas concentration. If a specified parameter is exceeded, further analysis of a second set of properties and a possible Watch List classification would be warranted. A tank can be removed from a Watch List if it is classified as SAFE. As of January 1995, tank SX-115 was classified as a non-Watch List tánk,

To meet the sampling requirements of this DQO effort, a vertical profile of the tank waste shall be obtained from at least two widely spaced risers. This vertical profile may be obtained using core, auger, or grab samples. The safety screening analyses shall be applied to al1 core samples, DST Resource Conservation and Recovery Act (RCRA) samples, and all auger samples, except those taken exclusively to assess the flammable gas crust burn issue. 


\subsection{PRETREATMENT DATA QUALITY OBJECTIVES}

Interim Data Quality Objectives for Waste Pretreatment and Vitrification (Kupfer et a1. 1994) addresses the characterization needs for the Pretreatment, High-Level Waste Disposal, and Low-Level Waste Disposal programs. These programs are responsible for developing long-term treatment and storage processes for the Hanford Site Haste. This effort will require comprehensive physical and chemical information from waste tank samples. The Pretreatment process must be able to separate the waste into feed streams that satisfy the safety issues associated with the operating requirements for the low-level and high-level vitrification facilities.

\subsection{TANK AND WASṪE INFORMATION}

This section summarizes the available historical information for SX-115. Included are the age of the tank, process history, and the expected contents of the tank based on historical information in Historical Tank Content Estimate for the SW Quadrant of the Hanford 200 West Area (Brevick et a1. 1994). The fill history information is available in A History of the 200 Area Tank Farms (Anderson 1990).

\subsection{TANK STATUS}

As of December 1994, tank $S X-115$ is a non-Watch List tank and is passively ventilated with interim stabilization completed in 1978. The tank is classified as an assumed leaker in 1965 and intrusion prevention measures were completed in 1982. Approximately 45,000 liters ( 12,000 gallons) of waste, consisting of 22,700 1iters ( 6,000 gallons) of sludge and 22,700 liters $(6,000$ gailons) of unknown waste with no pumpable liquid remaining are contained in the tank. The waste level measures about 25 centimeters (10 inches) in depth. The last solids update was obtained April 28, 1982. The last photograph taken March 18, 1988, revealed a dry, dark brown surface

(Brevick et al. 1994). Temperature data, have not been available since 1991 because the thermocouple tree has been out of service (Hanlon 1995).

\subsection{TANK CONFIGURATION}

Single-shell tank SX-115 was constructed as a type IV tank between 1953 and 1954 and is located in the 200 West Area. Tank SX-115 is 23 meters (75 feet) in diameter and has a capacity of 3,800,000 liters ( $1,000,000$ gallons). The tank is third in a three tank cascade flow system which includes tanks SX-113, 241-SX-114, and 241-SX-115. When the primary tank in the system became fu11, the waste would then flow to the secondary tanks in the system.

\subsection{TANK HISTORY}

Single-she11 tank SX-115 was constructed between 1953 and 1954 . Tank SX-115 was declared as an assumed leaker and removed from service in 1965 with a leak volume of 190,000 liters (50,000 gallons). Interim stabilization was declared in November 1978 and instursion prevention completed in September 1982. This tank contains non-complexed waste (NCPLX) with a total waste volume of 45,000 liters $(12,000$ gallons $)$. The waste is comprised of 22,700 liters $(6,000$ gallons) of 
unknown waste and 22,700 liters ( 6,000 gallons) of sludge with no pumpable liquid remaining. Figure 3-1 summarizes the influx and effluent history of tank SX-115 (Anderson 1990).

\subsection{EXPECTED TANK CONTENTS}

Tank SX-115 is expected to contain two primary layers of waste in the following order: Redox waste and an upper layer which is a supernate composed of unknown waste. Nitrate is present in high concentrations and plutonium is present in low concentrations (Brevick et al. 1994). An estimated inventory based on historical sample and analys is data is shown in Table 3-1 (Brevick et al. 1994). 
WHC-SD-WH-TP-325, ReV. 0

Table 3-1: Tank SX-115 Solid Composite Inventory Estimate

\begin{tabular}{|c|c|c|}
\hline Total solid waste & \multicolumn{2}{|c|}{$6.92 E+04 \mathrm{~kg}(12 \mathrm{kgal})$} \\
\hline Heat load & \multicolumn{2}{|c|}{$0.16 \mathrm{~kW}(5.53 \mathrm{E}+02 \mathrm{BTU} / \mathrm{hr})$} \\
\hline Bulk density & \multicolumn{2}{|l|}{$1.52 \mathrm{~g} / \mathrm{cc}$} \\
\hline Void Fraction & \multicolumn{2}{|l|}{0.68} \\
\hline TOC wt\% C (wet) & \multicolumn{2}{|l|}{0.01} \\
\hline Hater wt\% & \multicolumn{2}{|l|}{43.66} \\
\hline chemolal constutuents & \multicolumn{2}{|c|}{ 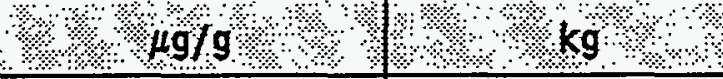 } \\
\hline $\mathrm{Na}^{+}$ & $9.76 \mathrm{E}+04$ & $6.76 E+03$ \\
\hline$A 7^{3+}$ & $4.40 E+04$ & $3.04 E+03$ \\
\hline $\mathrm{Fe}^{3+}($ total $\mathrm{Fe})$ & $1.54 E+03$ & $1.07 E+02$ \\
\hline $\mathrm{Cr}^{3+}$ & $9.50 E+03$ & $6.57 E+02$ \\
\hline $\mathrm{OH}^{-}$ & $9.60 E+04$ & $6.64 E 0+03$ \\
\hline $\mathrm{NO}^{3-}$ & $2.25 E+05$ & $1.56 E+04$ \\
\hline $\mathrm{NO}^{2-}$ & $1.69 E+03$ & $1.17 \mathrm{E}+02$ \\
\hline $\mathrm{CO}_{3}^{2-}$ & $8.12 E+03$ & $5.62 E+02$ \\
\hline $\mathrm{PO}_{4}^{3-}$ & 1.67E+03 & $1.16 E+02$ \\
\hline $\mathrm{SO}_{4}^{2-}$ & $7.77 \mathrm{E}+03$ & $5.37 \mathrm{E}+02$ \\
\hline$F^{-}$ & $2.25 E+02$ & 15.6 \\
\hline $\mathrm{Cl}^{-}$ & 84.47 & 5.84 \\
\hline $\mathrm{C}_{6} \mathrm{H}_{5} \mathrm{O}_{7}^{3-}$ & $2.69 E+02$ & 18.61 \\
\hline HEDTA ${ }^{3-}$ & 0.62 & $4.32 E-02$ \\
\hline ৷ ২ & gical Constituents & 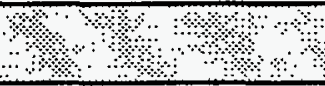 \\
\hline $\mathrm{Pu}$ & $\begin{array}{l}5.83 \mathrm{E}-02 \\
(\mu \mathrm{Ci} / \mathrm{g})\end{array}$ & $6.72 E-02(\mathrm{~kg})$ \\
\hline U & $1.98 \mathrm{E}+03(\mu \mathrm{g} / \mathrm{g})$ & $1.37 \mathrm{E}+02(\mathrm{~kg})$ \\
\hline Cs & $\begin{array}{l}1.02 E+02 \\
(\mu \mathrm{Ci} / \mathrm{g})\end{array}$ & $7.03 \mathrm{E}+03$ (Ci) \\
\hline Sr & $2.77 \mathrm{E}+02(\mu \mathrm{Ci} / \mathrm{g})$ & $1.92 E+04(\mathrm{Ci})$ \\
\hline
\end{tabular}




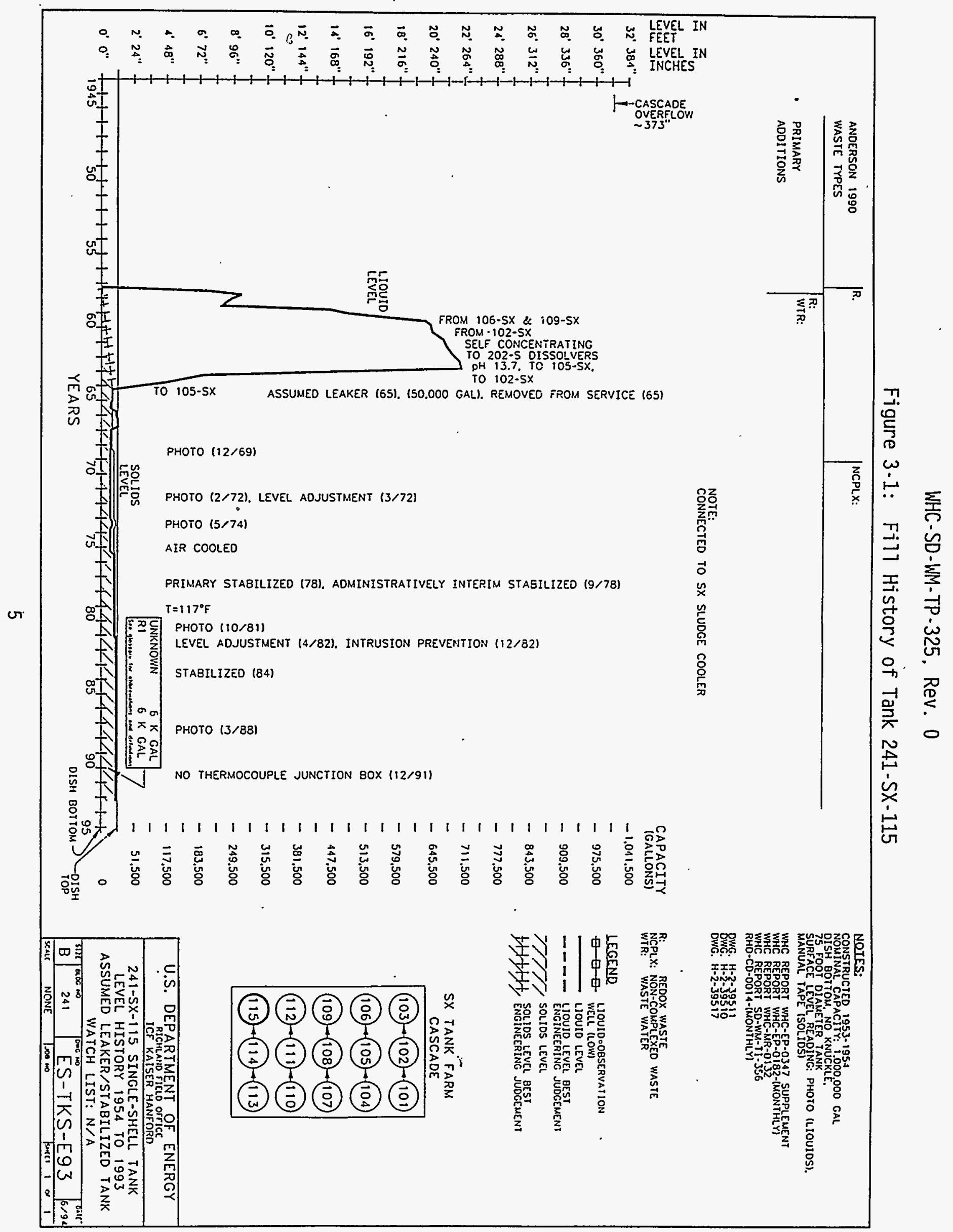




\subsection{TANK SX-115 SCHEDULED SAMPLING EVENTS}

Because there is only a small amount of waste in tank SX-115, sampling of this tank will not add much to the knowledge of waste in the tank farms as a whole. However, in order to address the data requirements of the Tank Safety Screening Data Quality Objective (Babad and Redus 1994), sampling of the tank will be performed. The only known sample from tank SX-115 was in 1975; that sample indicated a low moisture content, which is of concern.

Because of the low inventory of waste and lack of pumpable liquids in tank SX-115, auger sampling is the most appropriate sampling method to employ. Using the auger sampling technique, conservative energetics and moisture content data wil1 be established for the waste currently contained in tank SX-115. These conservative data will enable a specific safety category to be determined for tank $S X-115$ in accordance with the Tank Safety Screening Data Quality Objective (Babad and Redus 1994).

Only one sampling event for tank SX-115 is currently scheduled: an auger sample in June 1995. No other sampling of tank SX-115 is scheduled through Fiscal Year 1997 (Stanton 1995). The auger sampling shall be conducted following the Tank Safety Screening Data Quality Objective (Babad and Redus 1994) and Interim Data Quality Objective for Waste Pretreatment and Vitrification (Kupfer et a1. 1994). Sampling and analytical requirements from these DQOs are summarized in Table 4-1. A more complete list of analytical requirements are given, as an appended attachment, in the appropriate Sampling and Analysis Plan (SAP).

Table 4-1: Integrated DQO Requirements

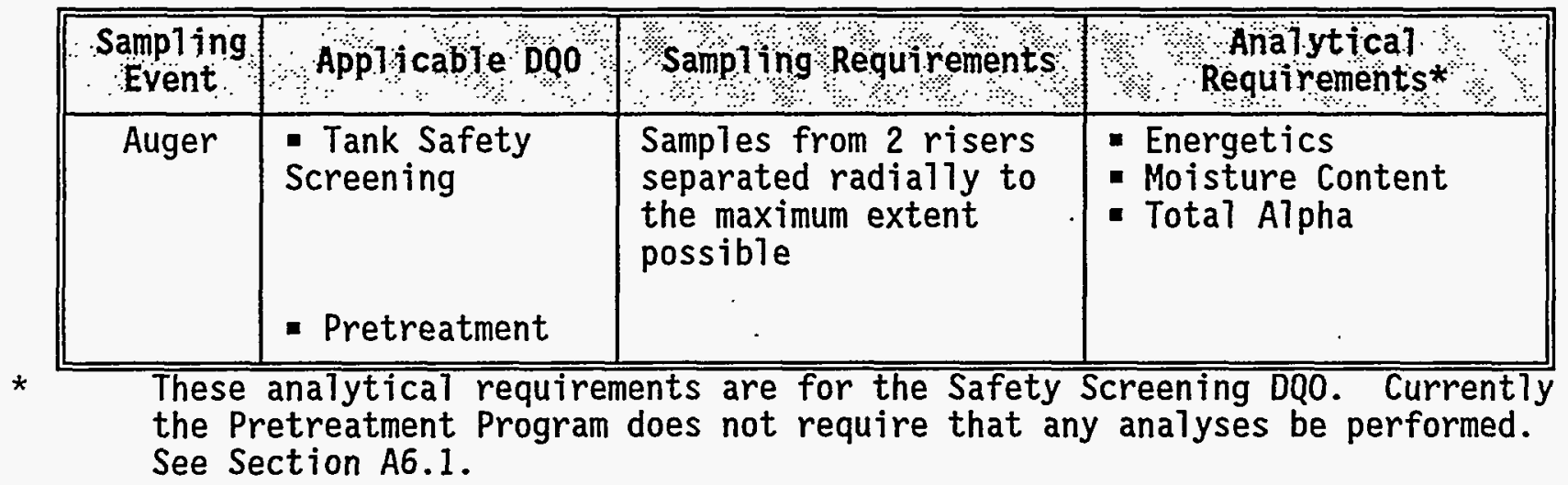




\subsection{REFERENCES}

Anderson, J. D., 1990, A History of the 200 Area Tank Farms, WHC-MR-0132, Westinghouse Hanford Company, Richland, WA.

Babad, H. and K. S. Redus, 1994, Tank Safety Screening Data Quality Objective, WHC-SD-WM-SP-004, Rev. 0, Hestinghouse Hanford Company, Richland, WA.

Brevick, C. H., L. A. Gaddis, and W. W. Pickett, 1994, Historical Tank Content Estimate for the SW Quadrant of the Hanford 200 West Area, WHC-SD-WM-ER-352, Rev. 0, ICF Kaiser Hanford Company, Richland, WA.

Conway, J. T., Letter to H.R. O'Leary, DOE, "DNFSB Recommendation 93-5 to the Secretary of Energy." 9400070, dated Ju1y 19, 1993.

Ecology, EPA, and DOE, 1994, Hanford Federal Facility Agreement and Consent Order, Fourth Amendment, Washington State Department of Ecology, U.S.

Environmental Protection Agency and U.S. Department of Energy, 07ympia, Washington.

Hanton, B. M., 1995, Waste Tank Summary for Month Ending December 31, 1994, WHC-EP-0182-81, Westinghouse Hanford Company, Richland, WA.

Kupfer, M. J., J. M. Conner, R. A. Kirkbride, and J. R. Mobley, 1994, Interim Data Quality Objective for Waste.Pretreatment and Vitrification, WHC-SD-WM-DQ0-011, Rev. 1, Westinghouse Hanford Company, Richland, Washington.

Stanton, G. A., 1995, Baseline Sampling Schedule, Revision 4.1, (Internal Memo 74320-95-01, to distribution, February 2), Westinghouse Hanford Company, Richland, WA. 
WHC-SD-WH-TP-325, Rev. O

\section{APPENDIX A}

\section{SAMPLING AND ANALYSIS PLAN}

\section{FOR AUGER SAMPLING IN FISCAL YEAR 1995}


WHC-SD-WM-TP-325, Rev. 0

TABLE OF CONTENTS FOR APPENDIX A

Al.0 SPECIFIC TANK CHARACTERIZATION OBJECTIVES .............. A-I

A2.0 TANK STATUS AND SAMPLING INFORMATION ............. A-1

A2.1 TANK STATUS .........................

A2.2 SAMPLING INFORMATION $\ldots \ldots \ldots \ldots$

A3.0 SAMPLE EXTRUSION AND BREAKDOWN INSTRUCTIONS ........... A-2

A3.1 TANK-SPECIFIC ANALYTICAL PROCEDURES ........... A-2

A3.2 INSUFFICIENT SAMPLE RECOVERY ............. A-5

A3.3 PRIORITIES OF REQUESTED ANALYSES ............ A-5

14.0 SPECIFIC ANALYTE, QUALITY ASSURANCE, AND DATA CRITERIA ....... A-9 A4.1 SPECIFIC METHODS AND ANALYSES . . . . . . . . . . . A A-9

A4.2 QUALITY ASSURANCE .................. A-9

A4.2.1 Laboratory Operations . . . . . . . . . . . . . A-9

A4.2.2 Sample Collection ................ A-9

A4.2.3 Sample Custody . . . . . . . . . . A-10

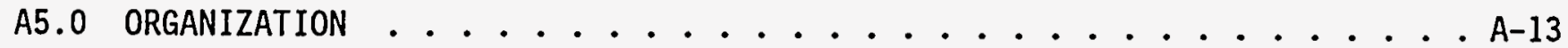

A6.0 EXCEPTIONS, CLARIFICATIONS, AND ASSUMPTIONS ............ A-13 A6.1 EXCEPTIONS TO DQO REQUIREMENTS .................. . A-13

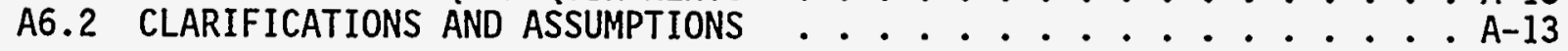

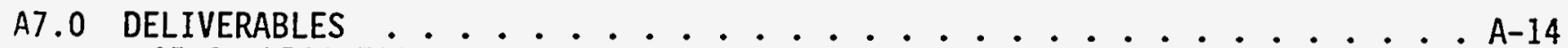

A7.1 PROGRESS REPORTS .................. . . . . . . . .

A7.2 FORMAT I REPORTING $\ldots \ldots \ldots$. . . . . . . . . . . . .

A7.3 FORMAT III REPORTING $\ldots \ldots \ldots \ldots$ A-15

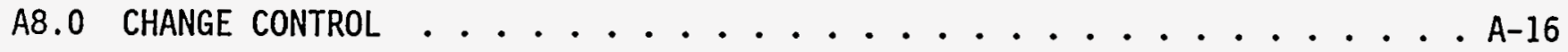

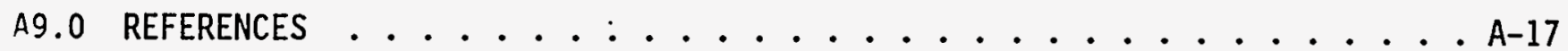


WHC-SD-WM-TP-325, Rev. 0

\section{LIST OF TABLES FOR APPENDIX A}

A-1: Tank SX-115 Chemical, Radiological and Physical Analytical

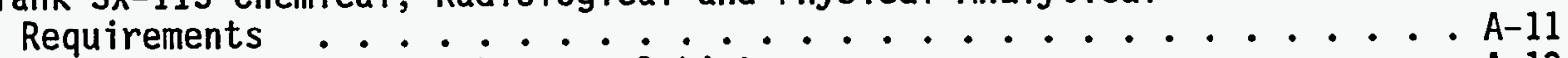

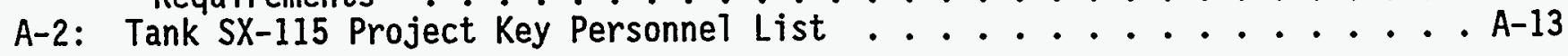

LIST OF FIGURES FOR APPENDIX A

A-1: Solid Analysis Flow Chart . . . . . . . . . . . . . . . . . A-6

A-2: Liquid Analysis Flow Chart . . . . . . . . . . . . . . . . . A-7

A-3: Sample Analysis and Reporting Flow Chart . . . . . . . . . . . . A-8

\section{LIST OF ABBREVIATIONS FOR APPENDIX A}

$\begin{array}{ll}\text { ACL } & \text { Analytical Chemistry Laboratory } \\ \text { DOE } & \text { Department of Energy } \\ \text { DQD } & \text { Data Quality Objective } \\ \text { DSC } & \text { Differential Scanning Calorimetry } \\ \text { DST } & \text { Double-Shel1 Tank } \\ \text { GEA } & \text { Gamma Energy Analysis } \\ \text { HPGE/MCA } & \text { High Purity Germanium-multi channel analysis } \\ \text { IC } & \text { Ion Chromatography } \\ \text { ICP } & \text { Inductively Coupled Plasma - atomic emission spectroscopy } \\ \text { LIMS } & \text { Laboratory Information Management Systems } \\ \text { RCRA } & \text { Resource Conservation and Recovery Act of 1976 } \\ \text { RSST } & \text { Reactive System Screening Tool } \\ \text { SARP } & \text { Safety and Analysis Report for Packaging } \\ \text { SAP } & \text { Sampling and Analysis PTan } \\ \text { SST } & \text { Single-Shel1 Tank } \\ \text { SX-115 } & \text { Tank 241-SX-115 } \\ \text { TCP } & \text { Tank Characterization PIan } \\ \text { TGA } & \text { Thermogravimetric Analysis } \\ \text { TOC } & \text { Total Organic Carbon } \\ \text { TWRS } & \text { Tank Waste Remediation System } \\ \text { USQ } & \text { Unreviewed Safety Question } \\ \text { WHC } & \text { Westinghouse Hanford Company }\end{array}$


WHC-SD-WH-TP-325, Rev. 0

\section{A1.0 SPECIFIC TANK CHARACTERIZATION OBJECTIVES}

This Sampling and Analysis Plan will identify characterization objectives for sample collection, hot cell sample breakdown, and laboratory analytical evaluation and reporting requirements in accordance with the Tank Safety Screening Data Quality objective (Babad and Redus 1994) and Interim Data Quality Objective for Waste rretreatment and Vitrification (Kupfer 1994). These Data Quality Objectives (DQ0s) are described in the Tank Characterization Plan (TCP) for tank 241-SX-115 (SX-115). The pretreatment DQO, at the request of the Pretreatment Program, will have limited use in this SAP (refer to section A6.1). This Sampling and Analysis Plan will also identify procedures and requirements, for collecting and characterizing samples from tank SX-115 by the auger sampling method.

\section{A2.0 TANK STATUS AND SAMPLING INFORMATION}

\section{A2.1 TANK STATUS}

Tank SX-115 was classified as an assumed leaker in 1965. Tank SX-115 is a non-Watch List tank and is passively ventilated with interim stabilization completed in 1978 and intrusion prevention measures completed in 1982. Tank SX-115 currently contains 45,000 liters ( 12,000 gallons) of non-complexed waste. The waste is comprised of 22,700 liters (6,000 gallons) of unknown waste and 22,7007 iters $(6,000$ gallons) of sludge with no pumpable liquid remaining. This volume of waste corresponds to approximately 25 centimeters (10 inches) of waste. The last solids update was obtained April 28, 1982 and in the latest photograph, taken March 18, 1988, the surface appears a dry dark brown. The temperature is not availabel because the thermocouple tree has been out of service since December 1991 (Hanton 1995).

\section{A2.2 SAMPLING INFORMATION}

Tank SX-115 is scheduled to be sampled by the auger sampling method. Samples are expected to be taken from risers 3 and 6 . If a different riser is necessary to meet sampling and analysis requirements, this change must be recorded and approved in writing by the sampling cognizant engineer before sampling. The risers used may be recorded on a permanent data sheet or recorded directly in a work package.

Sampling shall be conducted following procedures and documentation included in tank SX-115 work package WS-95-0070. If the sampling depth is within \pm 5 inches of the current depth information, one 20 inch auger bit will be used for the sampling of each riser. In the event that the current depth information is incorrect, a different sized auger bit may be used. The objective of the sampling event is to reach the inner bottom of the tank (bottom of. the waste) and the number of samples might change depending on the depth of the waste in the tank. 


\section{A3.0 SAMPLE EXTRUSION AND BREAKDOWN INSTRUCTIONS}

\section{A3.1 TANK-SPECIFIC ANALYTICAL PROCEDURES}

A flowchart depicting the sample breakdown and analysis scheme is presented in Figures $A-1, A-2$, and $A-3$. These steps are described in detail to provide the hot cel1 and laboratory chemists with guidance for the breakdown of the samples and may be altered as appropriate by the performing laboratory. Several analyses listed in Table A-1 require a 45 day reporting time, as noted. The 45 -day reporting format, Format III, is explained in Section A7.3.

As a precautionary measure, the Safety and Analysis Report for Packaging (SARP) in the work procedure T0-080-090 ("Load/Transport Sample Cask(s)") has been reviewed for an safety issued involved with transportation of tank $S X-115$ auger samples. For tank SX-115 auger samples, the tranport sample casks must be vented every fifteen days from the time of the cask sealing to release any accumulated gas.

Any decisions, observations, or deviations and justifications made to this work pian or during the sample breakdown shall be documented in writing. These decisions and observations shall also be reported in the data report. The reporting formats for analyses are contained in Table $A-1$.

Step 1 Receive auger-samples at the laboratory in accordance with approved procedures.

Step 2 Conduct the following on the material from each sample:

- Perform a visual examination of the sample(s)

- Record observations. This may include a sketch of the sample in addition to written documentation of pertinent descriptive information such as color, texture, homogeneity, consistency.

- Note color and clarity of any drainable liquid.

- Report sample recovery results to the Characterization Program within one working day of sample breakdown.

- Take color photographs and/or a videotape to visualiy document the sample.

Step $3 A \quad$ Is drainable 1 iquid present?

Yes: $\quad$ Proceed to Step 3B

No: $\quad$ Proceed to Step 5A

Step 3B Separate any drainable liquid from the solids. Measure and record the volume. Retain drainable liquids for further processing.

Step 4 Is the sample $100 \%$ drainable liquid?

Yes: $\quad$ Proceed to Step 14

No: $\quad$ Proceed to Step 5A 


\section{SOLIDS PATH}

Step $5 \mathrm{~A}$ Is there a hard, dry layer on the top of the auger sample?

Yes: $\quad$ Proceed to Step 5B

No: $\quad$ Proceed to Step 5C

Step 5B Separate the hard, dry layer and retain for analysis.

Step 5C Divide each auger sample into two equal subsample (i.e., half samples).

Step 6 Homogenize each subsample using the appropriate approved procedure.

Step 7 Will a homogenization test be performed ?

Yes: $\quad$ Proceed to Step 8

No: $\quad$ Proceed to Step 9

NOTE: One subsample per auger, at a minimum, should be used if a homogenization test is to be performed. Additional tests may be performed at the laboratory's discretion.

Step 8 Conduct the homogenization test by taking 1 to $2 \mathrm{~g}$ aliquot from widely separated locations of the homogenized subsample. Conduct the homogenization test in accordance with Bel1 (1993).

Step 9 Collect sufficient aliquots from each homogenized subsample to perform the appropriate preparations and analyses listed in Table A-1 in dup Ticate.

NOTE: If there is an insufficient amount of sample available in any subsample to perform all required analyses on the subsample, notify the Characterization Program within one business day and follow the prioritization of analyses given in Section A3.3.

Step 10 Remove at least $20 \mathrm{~mL}$ and ip to $40 \mathrm{~mL}$ of each homogenized subsample for the archive sample (Bratzel.1994).

Step 11 Combine subsamples proportional to the sludge recovery of the sample to build the solid composite.

Step 12 Remove $100 \mathrm{~mL}$ of the solid composite as the pretreatment solid composite archive (Bratze1 1994).

Step 13 Remove $125 \mathrm{~mL}$ of the solid composite for pretreatment process development work (see Section A6.2).

NOTE: If insufficient sample material is available to provide an archive and a sample for process development of the sizes described, divide the material remaining after Step 10 into equal portions (i.e., equal-sized portions for archive and process development work). 
Step 14 Closely inspect the liquid sample for the presence and approximate volume of any potential organic layers. Does the sample contain any immiscible (potentially organic) layers?

Yes: $\quad$ Proceed to Step 15A

No: $\quad$ Proceed to Step 16

Step 15A Report any visually observed immiscible (potential organic) layer immediately by the early notification system (see Section A7.2).

Step 15B Separate and retain the potential organic layer for possible future analysis.

NOTE: Steps 16 through 22 shall be performed on the remaining (probable aqueous) liquid layer only.

Step 16 Filter the remaining liquid sample through a 0.45 micron filter.

Step 17 Is there greater than 1 gram of solid on the filter?

Yes: $\quad$ Proceed to Step 18

No: $\quad$ Proceed to Step 19

Step 18 Archive the solids for possible future analysis (Bratzel 1994).

Step 19 Remove sufficient aliquots from the liquid sample to perform the appropriate analyses listed in Table A-1 in duplicate.

Step 20 Archive at least $20 \mathrm{~mL}$ and up to $40 \mathrm{~mL}$ of the drainable liquid as the liquid archive (Bratzel 1994).

Step 21 Combine the sample-level liquid proportional to the liquid recovery of the sample to build a liquid composite of the auger sample.

Step 22 Remove $100 \mathrm{~mL}$ of the liquid composite as the Pretreatment liquid composite archive (Bratzel 1994).

\section{PRIMARY ANALYSIS PATH}

Step 23 Perform primary analyses as listed in Table A-1.

Step 24 Compare the primary analysis data with notification limits.

Step 25A Do the results exceed the notification 7 imits (Table A-1)?

Yes: Proceed to Step 25B.

No: Proceed to Step 28.

Step 25B Report results exceeding the notification 1imits using Format I reporting deliverable requirements as listed in Section A7.2. 
WHC-SD-WM-TP-325, Rev. 0

\section{SECONDARY ANALYSIS PATH}

Step 26 Perform secondary analyses according to Table A-1.

Step $27 \mathrm{~A}$ Do the secondary analyses exceed the notification Timits?

Yes: Proceed to Step 27B

No: Proceed to Step 28

Step 27B Report results exceeding the notification limits using Format I reporting deliverable requirements as listed in Section A7.2.

Step 28 Report results as 1isted in Section A7.0.

\section{A3.2 INSUFFICIENT SAMPLE RECOVERY}

If the amount of material recovered from the samples taken from tank SX-115 is insufficient to perform the analyses requested and to permit a minimum $10 \mathrm{~mL}$ archive per sample, the laboratory shall notify the Tank Cognizant Engineer within one working day (See Table A-2). A prioritization of the analyses requested in this document is given in Section A3.3. Any analyses prescribed by this document, but not performed, shall be identified in the appropriate data report, with justification for non-performance.

\section{A3.3 PRIORITIES OF REQUESTED ANALYSES}

Confirmation of prioritization levels or revision of sample breakdown procedures may be provided to the laboratory by the Characterization Program based upon the sample recovery, readily observable physical property distinctions within the sample, and the requested sample breakdown procedures as provided in Section A3.1. The priority of an analysis is specified by its designation as a primary or secondary analysis. Further prioritization will be determined by the program on a DQO basis. 
WHC-SD-WM-TP-325, REV. 0

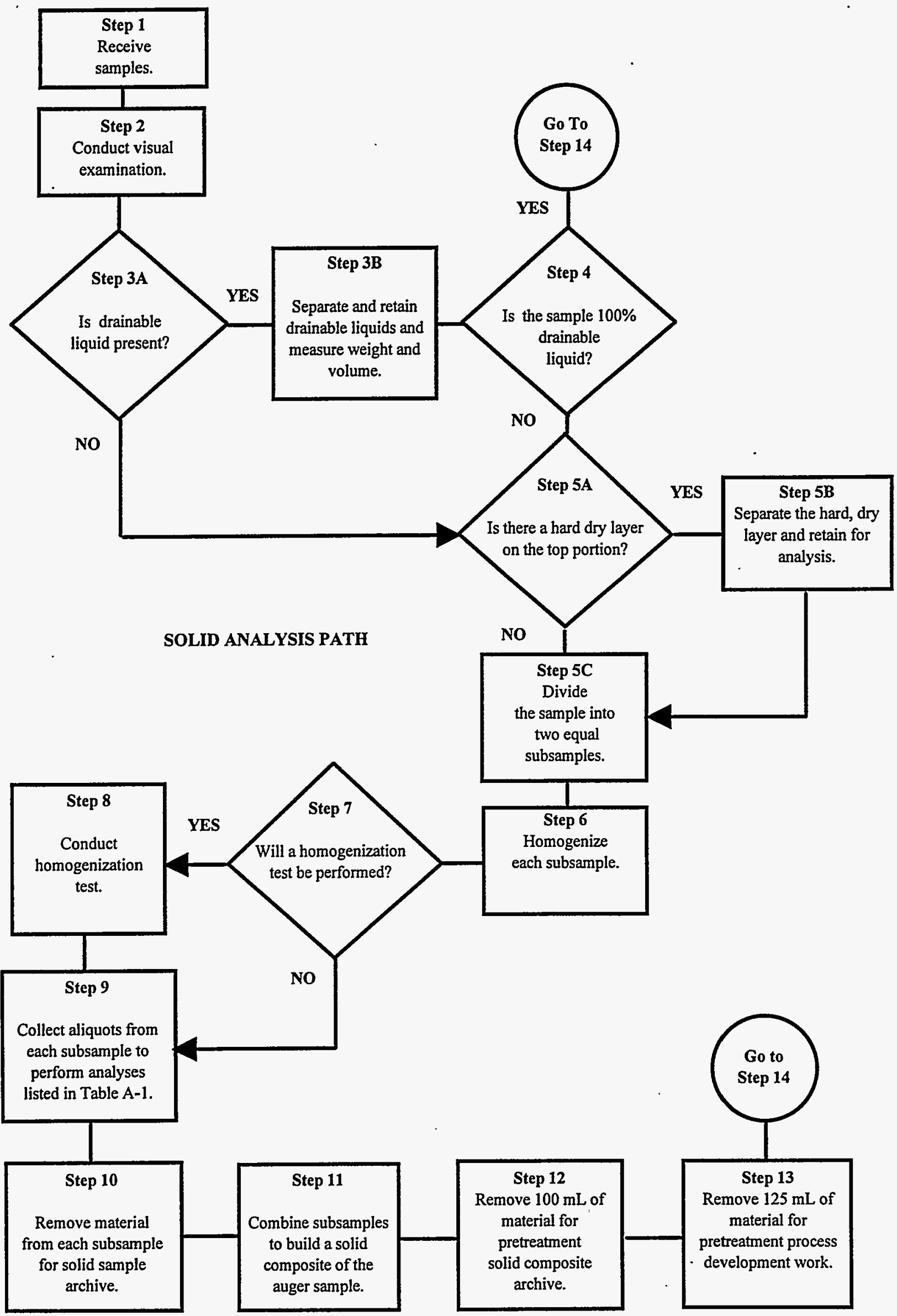

Figure A-1: Solid Analysis Flow Chart 


\section{LIQUIDS PATH}

WHC-SD-WM-TP-325, REV. 0

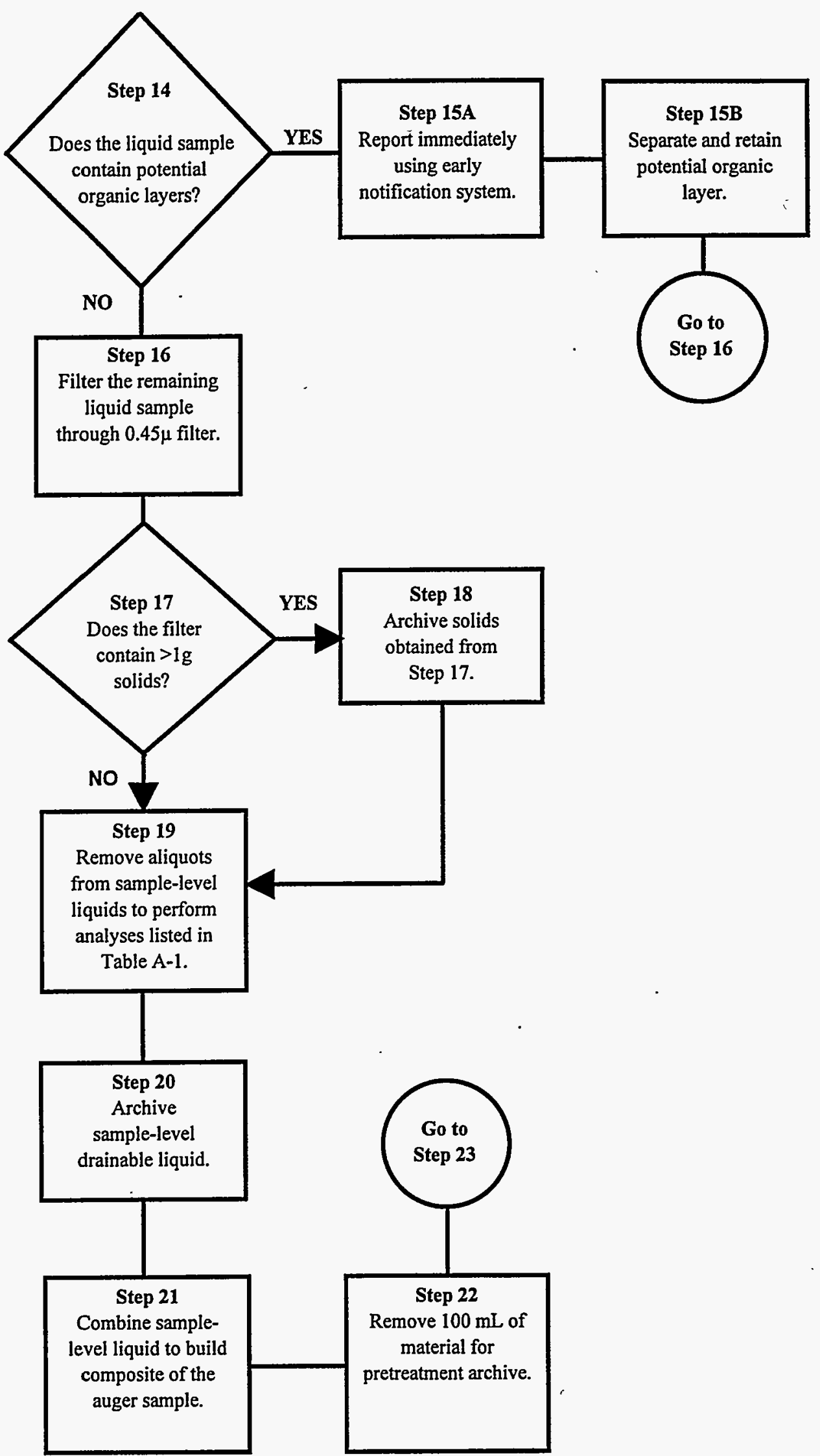

Figure A-2: Liquid Analysis Flow Chart 
WHC-SD-WM-325, REV. 0

Step 23

ANALYSES PATH

Perform primary

analyses as listed in

Table A-1.

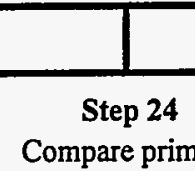

Compare primary

analysis data with

notification limits.

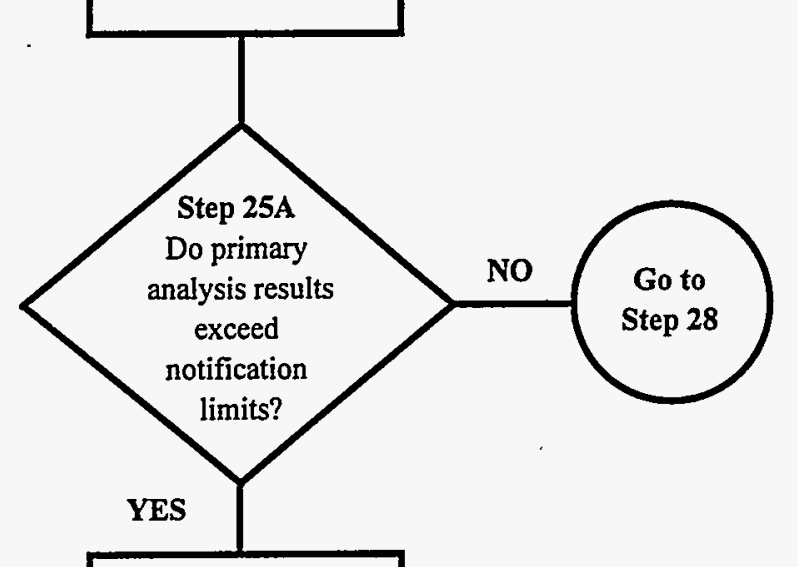

Step 25B

Report primary

analysis results using

Format I

deliverables.

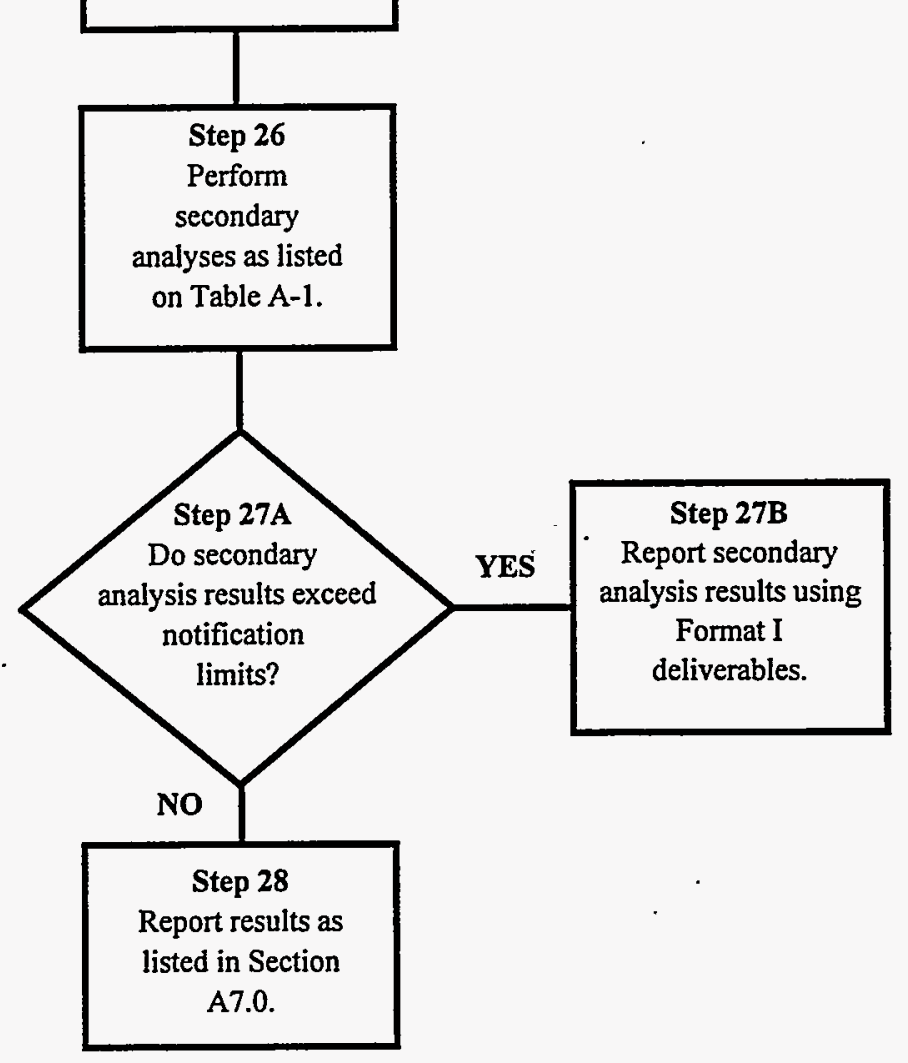

Figure A-3: Sample Analysis and Reporting Flow Chart 
WHC-SD-WM-TP-325, Rev. 0

\section{A4.0 SPECIFIC ANALYTE, QUALITY ASSURANCE, AND DATA CRITERIA}

\section{A4.1 SPECIFIC METHODS AND ANALYSES}

The analyses in Table A-1 to be performed on the tank SX-115 samples are based on the safety screening DQO referenced in Section A1.0. The laboratory procedure numbers, which shall be used for the analyses, are included in this table.

\subsection{QUALITY ASSURANCE}

\subsubsection{Laboratory Operations}

The WHC 222-S Laboratory has a quality assurance program plan (Meznarich 1994) and a quality assurance project plan (Taylor 1993) that shall provide the primary direction for the quality assurance of analyzing the waste tank samples at the WHC 222-S Laboratory. Additionally, the Hanford Analytical Services Quality Assurance P7an (DOE 1994), scheduled to be implemented (August of 1995), shall be used as quality assurance requirements.

Method specific quality control such as calibrations and blanks are also found in the analytical procedures. Sample quality control (duplicates, spikes, standards) are identified in Table A-1. If no criteria are provided in Table A-1, the performing laboratory shall perform to its quality assurance plan(s).

\section{A4.2.2 Sample Collection}

Two auger samples are to be taken from tank $S X-115$ and shipped to the performing laboratory by Sampling Operations in accordance with work package WS-95-0070. That work package shall also initiate the chain-of-custody for the samples. Approved work procedure T0-080-090 ("Load/Transport Sample Cask(s)") is to be used during the sampling event. Samples shall be identified by a unique number before being shipped to the performing laboratory. The sampling team is responsible for documenting any problems and procedural changes affecting the validity of the sample in a field notebook. Sampling Operations shall enter this information in the comment section of the chain-of-custody form for addition to the data reports.

Sampling Operations should transport each sample collected to the performing laboratory within one working day of removing the sample from the tank, but must transport each sample within three calendar days. Sampling Operations is responsible for verbally notifying the 222-S Laboratory (373-2435) at least 24 hours in advance of an expected shipment. 


\section{A4.2.3 Sample Custody}

The chain-of-custody form is initiated by the sampling team as described in work package WS-95-0070. Samples are shipped in a cask and sealed with a Waste Tank Sample Seal.

\begin{tabular}{||l|l|}
\hline \multicolumn{1}{|l|}{ Supervisor: } & Sample No.: \\
\hline Date of Sampling: & Time of Sampling: \\
\hline Shipment No.: & Serial No.: \\
\hline \hline
\end{tabular}

The sealed and labeled samples are shipped to the laboratory along with the chain-of-custody form. The receipt and control of samples in the WHC 222-S Laboratory are described in 1aboratory procedure L0-090-101. 
WHC-SD-WM-TP-325, REV. 0

Table A-1: Tank SX-115 Chemical, Radiological and Physical Analytical Requirements

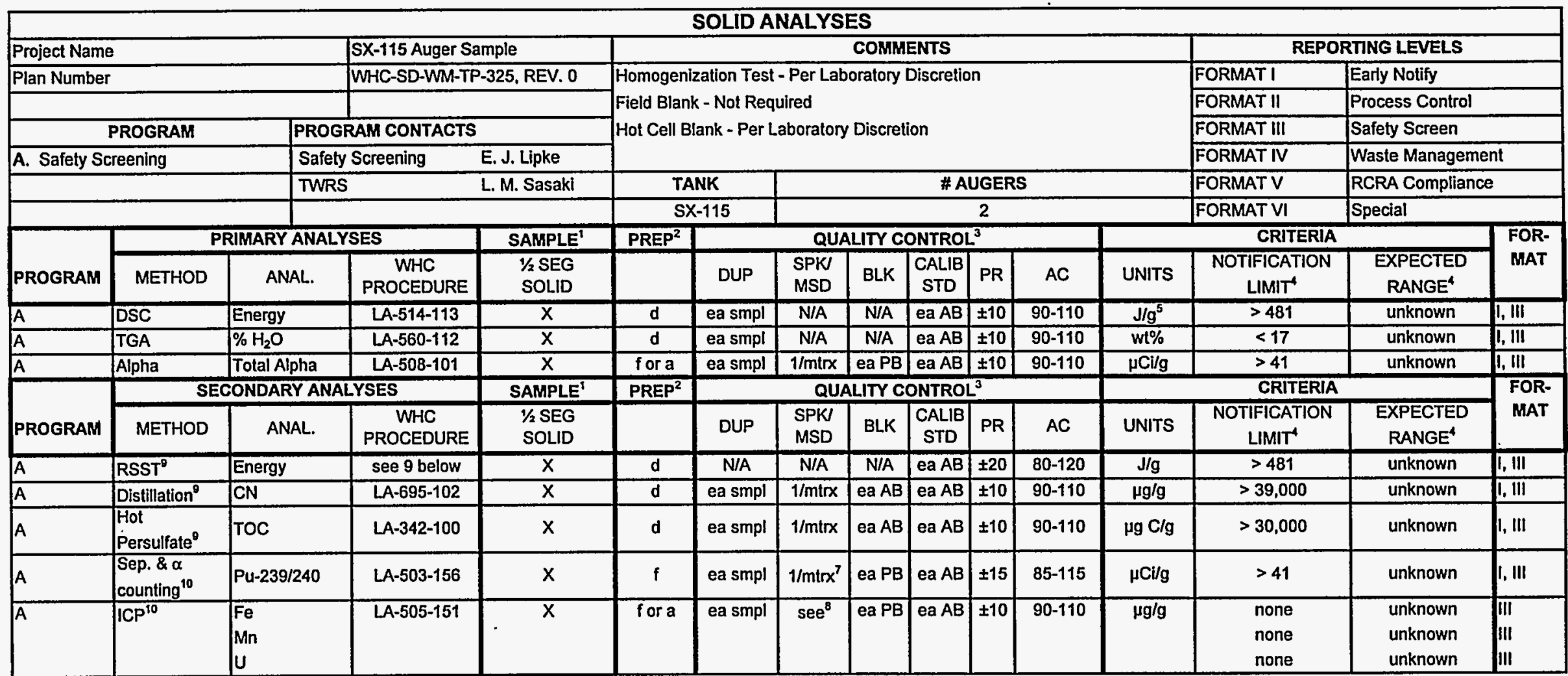

$11 / 2$ SEG SOLID-1/2 segment, solids

${ }^{2} \mathrm{~d}$-direct, f-fusion dissolution, a-acid dissolution, w-water dissolution

${ }^{3} \mathrm{PR}$-precision, AC-accuracy, ea-each, smpl-sample, DUP-duplicate, SPK/MSD-spike and matrix spike duplicate, AB-analytical batch, PB-preparation blank, N/A-not applicable, mtrx-matrix

"Units for notification limits and expected range are those listed in the "units" column.

${ }^{5}$ Dry weight basis.

${ }^{6}$ Direct liquid samples may be diluted in acid or water to adjust to proper sample size and/or $\mathrm{pH}$.

${ }^{7}$ Tracer or carrier may be used in place of a spike and results corrected for recovery.

'Either serial dilutions or matrix spikes will be performed.

${ }^{9}$ This analysis required if DSC exceeds notification limits. The RSST method, yet to be proceduralized, may be found in WHC-SD-WM-TP-104.

${ }^{10}$ Performed only if total alpha exceeds notification limit. 
WHC-SD-WM-TP-325, REV. 0

Table A-1: Tank SX-115 Chemical, Radiological and Physical Analytical Requirements

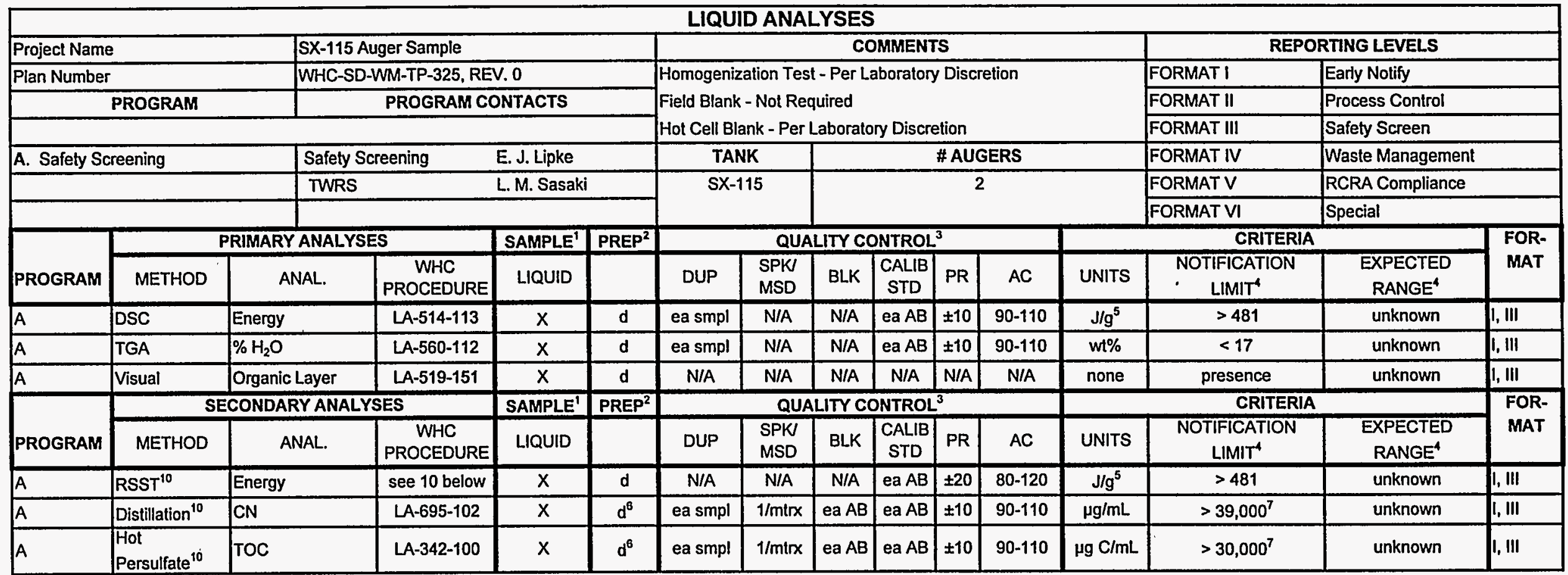

' LIQUID- segment level liquid

2d-direct, f-fusion dissolution, a-acid dissolution, w-water dissolution

${ }^{3}$ PR-precision, AC-accuracy, ea-each, smpl-sample, DUP-duplicate, SPKIMSD-spike and matrix spike duplicate, AB-analytical batch, PB-preparation blank, NIA-not applicable, mtrx-matrix

4Units for notification limits and expected range are those listed in the "units" column.

${ }^{5}$ Dry weight basis.

${ }^{6}$ Direct liquid samples may be diluted in acid or water to adjust to proper sample size and/or $\mathrm{pH}$.

${ }^{7}$ Action limit converted from weight basis assuming liquid density of $1.0 \mathrm{~g} / \mathrm{mL}$.

${ }^{8}$ Tracer or carrier may be used in place of a spike and results corrected for recovery.

${ }^{9}$ Either serial dilutions or matrix spikes will be performed.

${ }^{10}$ This analysis required if DSC exceeds notification limits. The RSST method, yet to be proceduralized, may be found in WHC-SD-WM-TP-104. 


\section{A5.0 ORGANIZATION}

The organization and responsibility of key personnel involved with this tank SX-115 characterization project are listed in Table A-2.

Table A-2: Tank SX-115 Project Key Personnel List

\begin{tabular}{|l|c|c|}
\hline Individual & Organization, & Respons bitity \\
\hline L. M. Sasaki & $\begin{array}{c}\text { TWRS } \\
\text { Characterization } \\
\text { PTans and Reports }\end{array}$ & TWRS Tank SX-115 Cognizant Engineer \\
\hline E. J. Lipke & WHC Safety Program & Safety Screening Point of Contact \\
\hline $\begin{array}{l}\text { West Tank Farm } \\
\text { Operations Shift } \\
\text { Manager }\end{array}$ & Tank Farm Operations & $\begin{array}{c}200 \text { West Tank Farm Point of Contact } \\
\text { if Action Limit is Exceeded } \\
\text { (373-3475) }\end{array}$ \\
\hline
\end{tabular}

\section{A6.0 EXCEPTIONS, CLARIFICATIONS, AND ASSUMPTIONS}

\section{$\therefore 6.1$ EXCEPTIONS TO DQO REQUIREMENTS}

In the safety screening DQO, it is specified that cyanide analyses are to be run on a quarter-segment level and that the notification limit for the DSC analysis is $125 \mathrm{cal} / \mathrm{g}$. The revised ferrocyanide DQO (Meacham et al. 1994) has changed the requirements such that the cyanide analys is is now to be run on a half-segment level and the DSC notification 7 imit is $115 \mathrm{cal} / \mathrm{g}$ (dry weight basis). This change will be incorporated in the next revision to the safety screening DQO. Therefore, although this Sampling and Analys is Plan uses the current safety screening DQO, it specifies that cyanide is to be run on a half-segment basis and that notification shall be made if the DSC value exceeds $481 \mathrm{~J} / \mathrm{g}(115 \mathrm{cal} / \mathrm{g})$ dry weight basis.

In the pretreatment $\mathrm{DQO}$, a wide array of analyses has been requested. However, it has been determined by the Pretreatment Program that all of these analyses are not necessary for these samples. If necessary, the Pretreatment Program wi71.personally contact the laboratory to run analyses on the archived composite samples. Therefore, the Pretreatment Program has directed that only a $125 \mathrm{~mL}$ composite solid sample for process development and a $100 \mathrm{~mL}$ composite sample for archive shall be obtained from this sampling event (Slankas 1995).

\section{$\triangle 6.2$ CLARIFICATIONS AND ASSUMPTIONS}

A number of clarifications and assumptions relating to the notification limits or decision thresholds identified in the applicable DQO efforts need to be made with respect to the analyses in Table A-1. Each of these issues are discussed below. 
- Any exotherm (in cal/g or $\mathrm{J} / \mathrm{g}$ ) determined by differential scanning calorimetry (DSC) must be reported on a dry weight basis as shown in equation (1) using the weight percent water determined from Thermogravimetric Analysis

$$
\text { Exotherm }(d r y w t)=\frac{[\text { exotherm (wet wt }) \times 100]}{\left(100-\frac{\text { water })}{8}\right.}
$$

NOTE: A large error in the DSC value may result when converting samples containing greater than $90 \%$ water to a dry weight basis. However, this conversion is still required.

- The safety screening DQO (Babad and Redus 1994) requires that additional analyses be performed if total alpha activity measures greater than $1 \mathrm{~g} / \mathrm{L}$. Total alpha is measured in $\mu \mathrm{Ci} / \mathrm{g}$ rather than $\mathrm{g} / \mathrm{L}$. To convert the notification limit for total alpha into a number more readily usable by the laboratory, it was assumed that all alpha decay originates from Pu-239. The notification limit may then be calculated as shown in equation (2):

$$
\left(\frac{1 g}{L}\right)\left(\frac{1 L}{10^{3} \mathrm{~mL}}\right)\left(\frac{1}{\text { density }} \frac{m L}{g}\right)\left(\frac{0.0615 C \dot{i}}{1 g}\right)\left(\frac{10^{6} \mu C \dot{i}}{1 C i}\right)=\frac{61.5}{\text { density }} \frac{\mu C i}{g}(2)
$$

NOTE: If a density of $1.5 \mathrm{~g} / \mathrm{mL}$ is assumed for solid material, the notification limit becomes $4 \mathrm{l} \mu \mathrm{Ci} / \mathrm{g}$.

- The safety screening DQO, upon which the analyses in Table A-I are based, does not sufficiently address the analyses of any drainable liquid present. To characterize the tank waste adequately, all analyses performed on the solids for the safety screening $D Q 0$, with the exception of total alpha analyses, shatt also be performed on any drainable liquid.

- The Pretreatment Program has requested $125 \mathrm{~mL}$ of the solid composite material for process development work. A test plan (Lumetta and Rapko 1994; Temer 1994) will be used to guide this process development work. Since the Characterization Program is responsible for the taking of tank samples, the Characterization Program will need to approve the test plan. This approval will not only ensure that the DQO process has been used in the generation of the test plan and that there is justification for the samples, but also that the facility receiving the samples is in an adequate position to handle radioactive material. At such time that the test plan is approved by the Characterization Program, the Characterization Program will direct the performing laboratory, via a letter of instruction, to allow shipment of the sample material to the performing laboratory.

\section{A7.0 DELIVERABLES}

A11 analyses of tank SX-115 waste material shall be reported as Formats I and/or III as indicated in Table A-1. Additional information regarding reporting rormats is given in Schreiber (1994a). 


\section{A7.1 PROGRESS REPORTS}

Each 1aboratory performing analyses on tank SX-115 waste material from this sampling project shal1 provide monthly status reports to the Characterization Program. This report shall contain 1) a summary of the activities on the analysis of tank $S X-115,2$ preliminary results to the program, and 3 ) schedule and cost information on a bQo basis.

Monthly and accumulative costs will be compared to the base as part of the progress report. Monthly variances greater than $10 \%$ or $\$ 10,000$, and accumulative variances greater than $\$ 50,000$ from the estimated costs or schedule must be ixplained in the report. Cost reporting shall consist of the following:

1. budgeted cost of work scheduled

2. monthly cost (actual cost of work performed)

3. year-to-date costs (actual cost of work performed)

Schedule reporting shall consist of the following:

1. monthly schedule

2. year-to-date scheduie

\section{$\triangle 7.2$ FORMAT I REPORTING}

Table A-1 contains the notification limits for each analyte. Any results exceeding their notification 7 imits shall be reported by calling the West Tank Farm Operations Shift Manager at 373-3475 and the Characterization Program Office (Schreiber 1994b). This verbal notification must be followed within 1 working day by written communication, documenting the observations, to Characterization Plans and Reports, Characterization Program office, Safety Screening Representative, and frocess Control. Points of contact within each program/project are defined by Schreiber (1995). Additional analyses for verification purposes may be contracted between the performing laboratory and the contacts above by a revision to this focument or by a letter of instruction.

\subsection{FORMAT III REPORTING}

A Format III report, reporting the results of the primary safety screen analyses shall be issued to the Safety Screening Representative, Characterization Plans and Reports, Characterization Program Office, Los A7amos Technical Associates (LATA), Tank Characterization Resource Center, Process Control, and the Tank Characterization Database representative within 45 days of receipt of the last sample at the laboratory loading dock. The DSC and TGA scans have been requested due to the interpretive nature of the analysis. If analyses for the safety screening secondary analytes are required, these results shall be provided within 90 days of receipt of the last sample at the laboratory loading dock. No calibration data are requested for these reports. Detailed information regarding the contents of this reporting format are given in (Schreiber 1994a). 


\section{WHC-SD-WH-TP-325, Rev. 0}

\section{A8.0 CHANGE CONTROL}

Under certain circumstances, it may become necessary for the performing laboratory to make decisions concerning a sample without review of the data by the customer or the Characterization Program. These changes shall be documented through the use of internal characterization change notices or analytical deviation reports for minor low-impact changes and documented in applicable laboratory reports. All significant changes (such as changes in scope) shall be documented by Characterization PIans and Reports via an Engineering Change Notice to this Tank Characterization Plan. All changes shall also be clearly documented in the final data report.

At the request of the Characterization Program, additional analysis of sample material from this characterization project shall be performed according to a revision of this plan. 


\section{A9.0 REFERENCES}

Rabad, H., 1992, An Overview of Progress Made Toward Resolving Priority One Safety Issues: Fiscal Year 1992, WHC-SD-WM-EP-0606, Westinghouse Hanford Company, Richland, Washington.*

Babad, H. and K. S. Redus, 1994, Tank Safety Screening Data Quality Objective, WHC-SD-WM-SP-004, Rev. 0, Hestinghouse Hanford Company, Rich7and, Washington.

Bel1, K. E., 1993, Tank Waste Remediation System Tank Waste Characterization Plan, WHC-SD-WM-PLN-047, Rev. 1, Westinghouse Hanford Company, Rich1and, Washington.

Bratzel, D. R., Letter to S. M. Joyce, "Archiving Requirements", 7E720-94-125, dated June 23, 1994.

nOE, 1994, Hanford Analytical Services Quality Assurance P7an, DOE/RL-94-55, Rev. 0, U. S. Department of Energy, Richland Field Office, Richland, Washington.

Haller, C. S., 1994, Fiscal Year 1995 Tank Waste Remediation System Tank Waste Analysis P7an, WHC-SD-WM-PLN-091, Rev. 0, Hestinghouse Hanford Company, Richland, Washington.*

Hanton, B. M., 1995, Waste Tank Summary for Month Ending December 31, 1994, WHC-EP-0182-81, Westinghouse Hanford Company, Richland, Washington.

Hil1, J. G., W. I. Winters, and B. C. Simpson, J. H. Buck, P. J. Chamberlain, V. L Hunter, 1991, Waste Characterization Plan for the Hanford Site Single-Shell Tanks, WHC-EP-0210, Rev. 3, Westinghouse Hanford Company, Richland, Washington.*

Kupfer, M. J., J. M. Conner, R. A. Kirkbride, and J. R. Mobley, 1994, Interim Data Quality Objective for Waste Pretreatment and Vitrification, WHC-SD-WM-DQO-011, Rev. 1, Westinghouse Hanford Company, Richland, Washington.

Lumetta, G. J. and B. M. Rapko, 1994, TWRS Pretreatment Technology Development Project: Sludge Washing and Caustic Leaching Screening Tests, PRT-TP-4.2, Rev. 0 , Pacific Northwest Laboratory, Richland, Washington.

Meacham, J. E., R. J. Cash, G. T. Dukelow, H. Babad, J. W. Buck, C. M. Anderson, B. A. Pulipher, J. J. Toth, and P. J. Turner, 1994, Data Requirements for the Ferrocyanide Safety Issue Developed through the Data Quality Objectives Process, WHC-SD-WM-DQO-007, Westinghouse Hanford Company, Richiand, Washington.

Meznarich, H. K., 1994, Quality Assurance Program P7an for Laboratory Analysis and Process Testing, HHC-SD-CP-QAPP-003, Rev. 1, Westinghouse Hanford Company, Richland, Washington.

Schreiber, R. D., 1994a, Letter to C. S. Haller, "Revised Interim Tank Characterization PIan Guidance", 7E720-94-121, dated May 13, 1994.

Schreiber, R. D., 1994b, Letter to J. G. Kristofzski, "Format I Reporting Requirement", 7E720-94-128, dated August 15, 1994. 
Schreiber, R. D., 1995, Letter to J. G. Kristofzski, "REVISION: Point of Contact/Distribution List", 71520-95-108 Reissue, dated March 23, 1995.

Slankas, J. T., 1995, Letter to R. D. Schreiber, TWRS-TDPO-95-009, dated February 2, 1995.

Taylor, L. H., 1993, Quality Assurance Project Plan for Chemical Analysis of Highly Radioactive Mixed Waste Samples in Support of Environmental Activities on the Hanford Site, WHC-SD-CP-QAPP-002 Rev. OA, Westinghouse Hanford Company, Richland, Hashington.

Temer, D. 1994, Los A7amos National Laboratory Test Plan for S7udge Washing and Caustic Leaching Test, Los Alamos National Laboratory, Los Alamos, New Mexico.

Whelan, T. E., 1994, TWRS Characterization Program Quality Assurance Program Plan, WHC-SD-WM-QAPP-025, Rev. 0, Westinghouse Hanford Company, Richland, Washington.*

*included as a bibliographical reference 